\title{
ELIMINATION OF EXCESSIVE NOISE AT THE OPEN OFFICE WORKPLACE
}

\author{
Pavol ČEKAN ${ }^{1}$, Miroslav RUSKO $^{1}$, Ján ILKKO ${ }^{2}$, Dieter PIETRUCHA ${ }^{3}$ \\ ${ }^{1}$ SLOVAK UNIVERSITY OF TECHNOLOGY IN BRATISLAVA, \\ FACULTY OF MATERIALS SCIENCE AND TECHNOLOGY IN TRNAVA, \\ INSTITUTE OF INTEGRATED SAFETY, \\ JÁNA BotTu 25, 91724 TRNAVA, SLOVAK REPUbliC \\ ${ }^{2}$ SLOVAK UNIVERSITY OF TECHNOLOGY IN BRATISLAVA, \\ FACULTY OF MATERIALS SCIENCE AND TECHNOLOGY IN TRNAVA, \\ INSTITUTE OF PRODUCTION TECHNOLOGIES, \\ JÁNA BotTu 25, 91724 TRNAVA, SLOVAK REPUBLIC \\ ${ }^{3}$ MEDON Gmbh, OLBENDORF, REPUBLIK ÖSTERREICH \\ IOTRONIC PROCESS MONITORING, LANGENARGEN AM BODENSEE, \\ BUNDESREPUBLIK DEUTSCHLAND \\ e-mail: pavol.cekan@stuba.sk, miroslav.rusko@stuba.sk \\ Received: 20.05.2019, Accepted: 12.06.2019, Published: 25.07.2019
}

\begin{abstract}
Open-plan office is a distraction to employee performance. According to a study by Cornell University, Ithaca, NY, working in a noisy office with ringtones, business conversations and office equipment sounds can lead to heart disease, because workplace noise causes stress. The paper focuses on noise analysis in an open-office work environment, the effect of noise on the selected operational position, as determined by standardized noise exposure $L_{E X, 8 h}$. Based on the results obtained, appropriate measures were proposed.
\end{abstract}

\section{Key words}

Noise, open-office, simulation, assessment, measurement

\section{INTRODUCTION}

There is no physical difference between sound and noise, and whether the noise is involved lies primarily with the recipient of the sound. People often combine noise with loud sounds that can damage their hearing, and therefore, when considering its possible health effects, noise can be defined as a loud noise that can cause hearing damage. Loud noises are not always perceived as noise, although they can affect human health, such as loud music during a concert. On the contrary, in some situations, even not very loud or potentially harmful sounds may be perceived as noise. Such sounds may prevent from concentrating at work which requires the involvement 
of mental abilities such as reading, writing or verbal communication. Noise is largely a subjective concept and can be defined as any unwanted, at a given moment, sound [1].

Workplaces where normal speech communication is an important means of management and communication, and where they are used for communicating also other means, excessive noise may be disturbing. Examples of such unwanted noise disturbance may be open-plan ofice workplaces. Today, many companies use open-plan offices designed to increase teamwork, better communication and productivity. However, studies show that these open interactive spaces are sources of a workplace noise spread and that noise as an unwanted sound is a common problem in such offices [2].

According to a Cornell University, Ithaca, N.Y., study, working in a moderately noisy office with ringing telephones, worker conversations, the sounds of office equipment whirring, and drawers opening and closing may lead to heart disease since workplace noise causes heartdamaging stress hormones to become elevated. "Open-plan space is the current 'fashion' in office design, partly because people believe it is more cost-effective, but also because it is conducive to the team concept many organizations have adopted," indicates Jack Heine, CEO of Cambridge (Mass.) Sound Management, an acoustical engineering and personal sound management company. "Whatever the impetus, more and more of these open offices are being built, which means there are more and more distractions and potential health hazards keeping workers from producing at their most efficient level" [3].

In another study, conducted for the American Society of Interior Designers, conversational noise was the number-one complaint of office workers and an overwhelming $70 \%$ said they would be more productive if there were noise distractions. Similarly, in a study by Armstrong World Industries, 52\% of workers reported that the noise level in their workplace was stressful and $81 \%$ said they could get more work accomplished if their workplace were quieter [3].

Exposure to noise can present a wide range of health and safety risks to workers. It is generally known, that a long-term and repeated exposure to noise has a negative impact on hearing. However, it is less known that not only auditory organs are affected by noise.

Many researches suggest that noise affects the entire organism, especially the central nervous system. [6] Table 1 describes the areas of effects of noise on the human body.

Table 1 Areas of noise effects on the human body [7]

\begin{tabular}{|c|c|c|}
\hline Area of operation & Noise value $[\mathrm{dB}]$ & Effects on the human organism \\
\hline \multirow{2}{*}{ Psychical action } & \multirow{2}{*}{ from $65 \mathrm{~dB}$} & it is not directly harmful to health, \\
\hline & & but decides individual sensitivity \\
\hline \multirow{4}{*}{ Vegetative function area } & 65 to $90 \mathrm{~dB}$ & $\begin{array}{l}\text { humans become more nervous, blood } \\
\text { vessels are narrow, }\end{array}$ \\
\hline & (while vigilance) & breathing is accelerated, heart activity rise, \\
\hline & 45 to $80 \mathrm{~dB}$ & pupils are widen, \\
\hline & (while sleeping) & stomach is clenching \\
\hline \multirow{2}{*}{ Hearing damage } & \multirow{2}{*}{90 to $120 \mathrm{~dB}$} & damage to the auditory cells, \\
\hline & & deafness can occur \\
\hline Fatal damage & over $120 \mathrm{~dB}$ & \\
\hline
\end{tabular}

High noise levels make it difficult for workers to hear and communicate, thereby increasing probability of accidents. Work-related stress, which may be a factor of noise, can multiply this problem [8].

Noisy offices may increase a worker's feelings of negative mood. In addition, studies have shown that certain levels of noise can incapacitate a person's ability to concentrate on 
a particular task, thereby leading to a stress respons. Increased stress leads to the release of certain chemicals, such as epinephrine and norepinephrine, which are found in both blood and urine. Prolonged exposure to stress has serious health effects. A study in the New England Journal of Medicine found that stress could cause insulin resistance, heart disease, memory loss, immune system dysfunction, and decreased bone mass density [4].

The following part of the paper is focused on the assessment of excessive noise in the railway traffic control workplace with the open-space office type .

\section{METHOD OF DETERMINING THE NOISE EXPOSURE}

Excessive noise exposure was monitored at the Traffic Management Center (TMC) of the Slovak Railways (ŽSR). As the railway infrastructure was modernised, it was necessary to provide an assessment of the exposure to excessive noise. As part of the modernization of the railway infrastructure of ŽSR, the fifth pan-European corridor in the section Bratislava-Rača Nové Mesto nad Váhom, the Traffic Control Center in the Trnava station was built. The current internal layout of the open-space office is shown in Figure 1. It uses a remote-controlled security device (DOZZ) for the remotely controlled track (RCT) Turnout Svätý Jur - Turnout Horná Streda. On the line Bratislava-Rača - Nové Mesto nad Váhom, the 3rd category security equipment, dispatcher construction type SIMIS W, computerized control level ILTIS with CTC extension is built; it allows the train to be operated from one location in intermediate stations. The dispatchers arrange and organize train transport at the railway station and in the adjacent railway sections of the remotely operated DOD (Turnout Svätý Jur - Pezinok - Šenkvice - Cífer - Trnava - Turnout Brestovany station - Leopoldov - Vel'ké Kostol'any - Piešt’any - Turnout Horná Streda) [11]. The TMC workplace in Trnava provides the management service information and emergency service by train in a controlled line section.

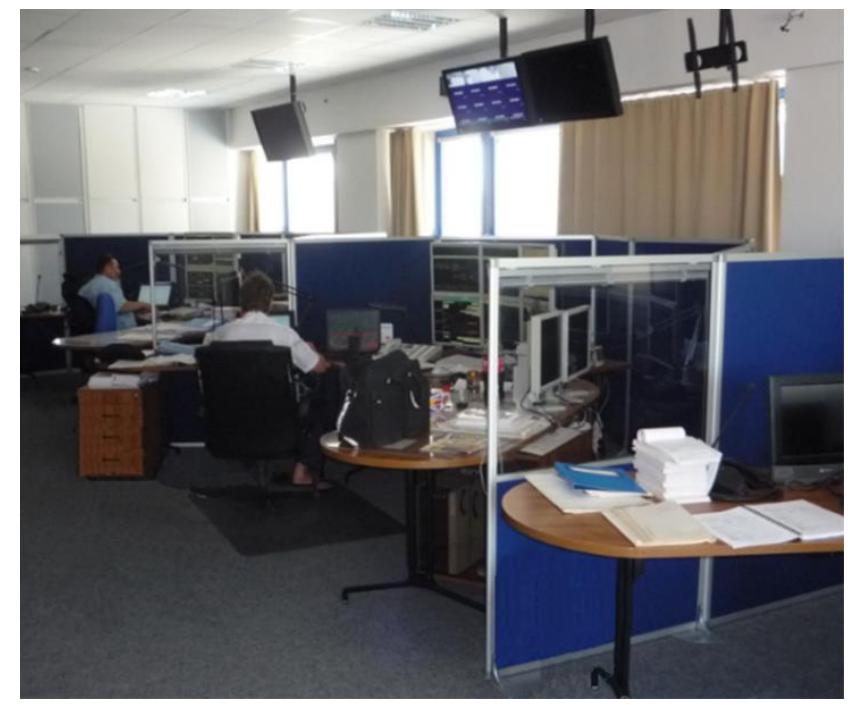

Fig. 1 View of the TMC workplace layout in Trnava [9]

Three traffic management posts are set up within the workplace:

- RCT 1 - provision, management and organization of train transport on the track section of Turnout Brestovany zastávka -Leopoldov - Vel'ké Kostol'any - Piešt'any - Turnout Horná Streda,

- RCT 2 - provision, management and organization of train transport in the Trnava district

- RCT 3 - security, management and organization of train transport on the railway section ofSvätý Jur-Pezinok-Šenkvice-Cífer. 
At every workplace, one dispatcher is on the RCT duty. The job consists of building and checking the construction of train paths, supervising the safety of employees working in the railways, keeping records and informing traffic controllers about the current train operation, solving emergency situations in case of failures, deficiencies, accidents and emergency situations, and communication with train staff [9].

The RCT dispatcher works in conjunction with train drivers, turnout cleaners, signal masters, turnout controllers, and other staff involved in radio and telephone operations. The RCT dispatchers are direct superiors to other train participants in the entrusted track section [9].

\section{Measuring strategy}

Measurement of equivalent sound pressure level $L_{A e q, T}$ in the operating environment of the Traffic Control Center was carried out in accordance with the Act 115/2006. To measure and determine the characteristics of the noise under consideration, a strategy was used to measure it using a sound level meter located at the head of the worker (up to $0.4 \mathrm{~m}$ from the worker's ear canal) - on the side with higher noise exposure, during the common performance of the job. The measurement interval was selected to adequately represent the average equivalent sound pressure level of the profession under consideration [10].

In accordance with the technical method of determining the exposure to noise in the working environment according to the Act 115/2006, the measurement was performed according to the steps listed in Table 2.

\begin{tabular}{|c|c|c|}
\hline Step 1 & Work analysis & $\begin{array}{l}\text { Finding sufficient information about the job and workers } \\
\text { in order to select a suitable measurement strategy, so that } \\
\text { measurements can be planned }\end{array}$ \\
\hline Step 2 & $\begin{array}{l}\text { Choosing a } \\
\text { measurement } \\
\text { strategy }\end{array}$ & $\begin{array}{l}\text { The measurement strategy must be selected based on the } \\
\text { following: } \\
\text { measurement of work task }(s) \\
\text { measurement of work type (profession) } \\
\text { or day-long measurements. If justified, more than one } \\
\text { measurement strategy may be used }\end{array}$ \\
\hline Step 3 & Measurement & $\begin{array}{l}\text { The basic measurement is } \mathrm{L}_{, A, e q T} \text {. If } \\
\text { necessary, the measured value is also } \mathrm{L}_{C P k, T}\end{array}$ \\
\hline Step 4 & $\begin{array}{l}\text { Checking for } \\
\text { errors and } \\
\text { uncertainty }\end{array}$ & $\begin{array}{l}\text { Sources of errors and uncertainties that may affect } \\
\text { the outcome are evaluated }\end{array}$ \\
\hline Step 5 & $\begin{array}{l}\text { Calculation and } \\
\text { indication of } \\
\text { measurement } \\
\text { results and } \\
\text { uncertainty }\end{array}$ & $\begin{array}{l}\mathrm{L}_{\mathrm{AEX}, 8 \mathrm{~h}} \text {.is calculated as determined for the selected } \\
\text { strategy measurements. }\end{array}$ \\
\hline
\end{tabular}

Measurements were made for the following selected professions:

- Measurements M1 - TMC profession: dispatcher 3, direction Bratislava, in the presence of worker, microphone placed at the head of the worker - up to $0.4 \mathrm{~m}$ from the worker's ear canal.

- Measurements M2 - TMC profession: 
- dispatcher 1 - direction Leopoldov, NMNV

- dispatcher 2 - Trnava

- dispatcher 3 - direction Bratislava

- manager 4

- operator 5

Determination of exposure and making calculations was done through the following relationships. Equivalent Level A acoustic pressure for the task (operation) $m$ of $I$ individual measurements $\mathrm{L}_{\mathrm{Aeq}, \mathrm{T}}$ is calculated using the equation (1):

$$
L_{A e q, T}=10 \log \left[\frac{1}{N} \sum_{i=1}^{n} 10^{0,1 \times L_{A e q, T}}\right] d B
$$

where:

$L_{A e q, T}$ - is the equivalent A level of acoustic pressure, for the task (operation) with $T$ duration $i$ - the serial number of the measurement for the task (operation),

$N$ - total number of measurements for the task (operation) [7].

Determining the daily exposure level of noise is defined by equation (2):

$$
L_{E X, 8 h}=10 \log \left[\sum_{m=1}^{M} \frac{\overline{T_{m}}}{T_{0}} 10^{0,1 \times L_{A e q, T}}\right] d B
$$

where:

$L_{A e q, T}$ - is the equivalent A level of acoustic pressure, for the task (operation) with $T$ duration $\bar{T}_{m}$ - the arithmetic average of working time $\mathrm{m}(12 \mathrm{~h})$,

$T_{0}$ - reference time interval $T O=8 h$,

$m$ - work order serial number,

$M$ - the total number of tasks m contributing to the daily exposure level [7].

Working hours: $06.00 \quad-18.00$, working time: $12 \mathrm{~h}$, time out: $0.25 \mathrm{~h}$. The measured values of the equivalent acoustic pressure level $L_{\text {Aeq,T }}$ are shown in Table 3.

\begin{tabular}{|c|c|c|c|c|c|}
\hline \multicolumn{2}{|c|}{ Table 3 Measured noise levelsv alues of individual professions } \\
\hline Profession & Operation & $\begin{array}{c}\text { Time interval of } \\
\text { measurement }\end{array}$ & $\begin{array}{c}\text { Measured } \\
\text { value } \\
\boldsymbol{L}_{\boldsymbol{A} \text { eq, }} \boldsymbol{T} \\
(\boldsymbol{d B})\end{array}$ & $\begin{array}{c}\text { Measured } \\
\text { value } \boldsymbol{L}_{\boldsymbol{C} \boldsymbol{k} \boldsymbol{k}} \\
(\boldsymbol{d B})\end{array}$ \\
\hline M1 & dispatcher 3 & $\begin{array}{c}\text { traffic } \\
\text { management }\end{array}$ & $11: 12-11: 17$ & 61,0 & 90,2 \\
\hline M2-5 & $\begin{array}{c}\text { dispatcher, } \\
\text { manager, } \\
\text { operator }\end{array}$ & $\begin{array}{c}\text { traffic } \\
\text { management }\end{array}$ & $11: 17-11: 24$ & 60,0 & 97,6 \\
\hline
\end{tabular}

An equivalent level determines the exposure for conversion of $L_{E X, 8 h}$ be extended if necessary, regarding the uncertainty of measurement and other necessary corrections [9]. 


\begin{tabular}{|c|c|c|c|c|c|c|c|}
\hline \multicolumn{8}{|c|}{ Working activity /measurement place - dispatcher 3} \\
\hline $\begin{array}{c}\text { Work } \\
\text { groups in } \\
\text { accordance } \\
\text { with Act } \\
\mathbf{1 1 5 / 2 0 0 6}\end{array}$ & $\begin{array}{c}\text { Measured } \\
\text { value } \\
\text { LAeq,T } \\
\text { [dB] }\end{array}$ & $\begin{array}{l}\text { Interva } \\
\text { l of } \\
\text { action } \\
\text { (hour) }\end{array}$ & $\begin{array}{l}\text { Measured } \\
\text { value } \\
\text { converted } \\
\text { to LAEX,8h } \\
\text { [dB] }\end{array}$ & $\mathbf{U}$ & $\begin{array}{c}\text { KT } \\
{[\mathrm{dB}]}\end{array}$ & $\begin{array}{l}\text { Assessed } \\
\text { value in } \\
\text { terms of } \\
\text { health } \\
\text { protection } \\
\text { LEX, 8h } \\
\text { [dB] }\end{array}$ & $\begin{array}{c}\text { Assessed } \\
\text { value for } \\
\text { work } \\
\text { groups } \\
\text { LAEX, 8h } \\
\text { [dB] }\end{array}$ \\
\hline II & 61 & 12 & 62.7 & 2 & 5 & 64.7 & 69.7 \\
\hline
\end{tabular}

To determine the $L_{E X, 8 h}$ value, the value of the dviation was added to the result $U$. Correction for the presence of an identifiable tone component in the noise spectrum was determined by the Act $115 / 2006$ as the value $K T=+5 d B$ [10].

Taking into account Amendment of the Act115/2006 Coll. on the highest permissible determining quantities of noise in the working environment, the character of noise, the addition of corrections and the uncertainty of measurement, it can be stated that the action value of the standardized level of $L_{A E X, 8 h}$ at the workplace of dispatcher No. 3 was exceeded for groups I, II and III [10]. The measured data show a clear excess of the noise exposure for the aforementioned work groups according to law. To determine the current state of the sound field, a simulation was performed in CadnaA software. Figure 2 shows the noise map of the workpleace in its original state.
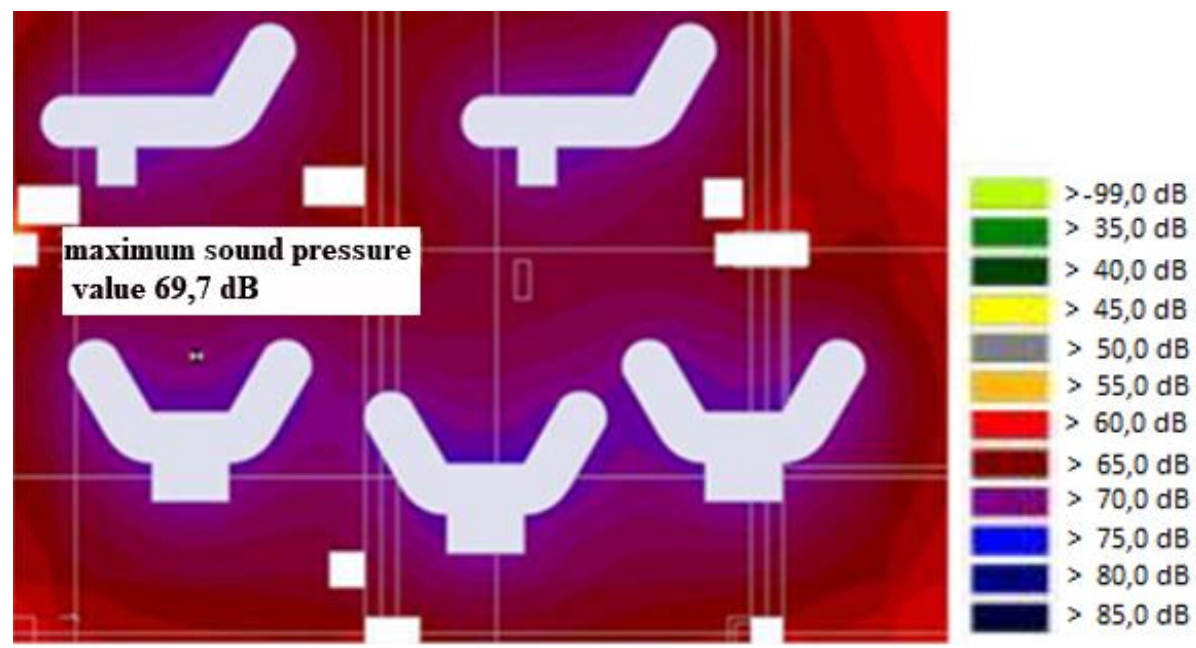

Fig. 2 Acoustic map of the TMC workplace in original condition [9]

Based on these failings, appropriate corrective actions have also been taken, the application of which is shown schematically in Figure 3. 


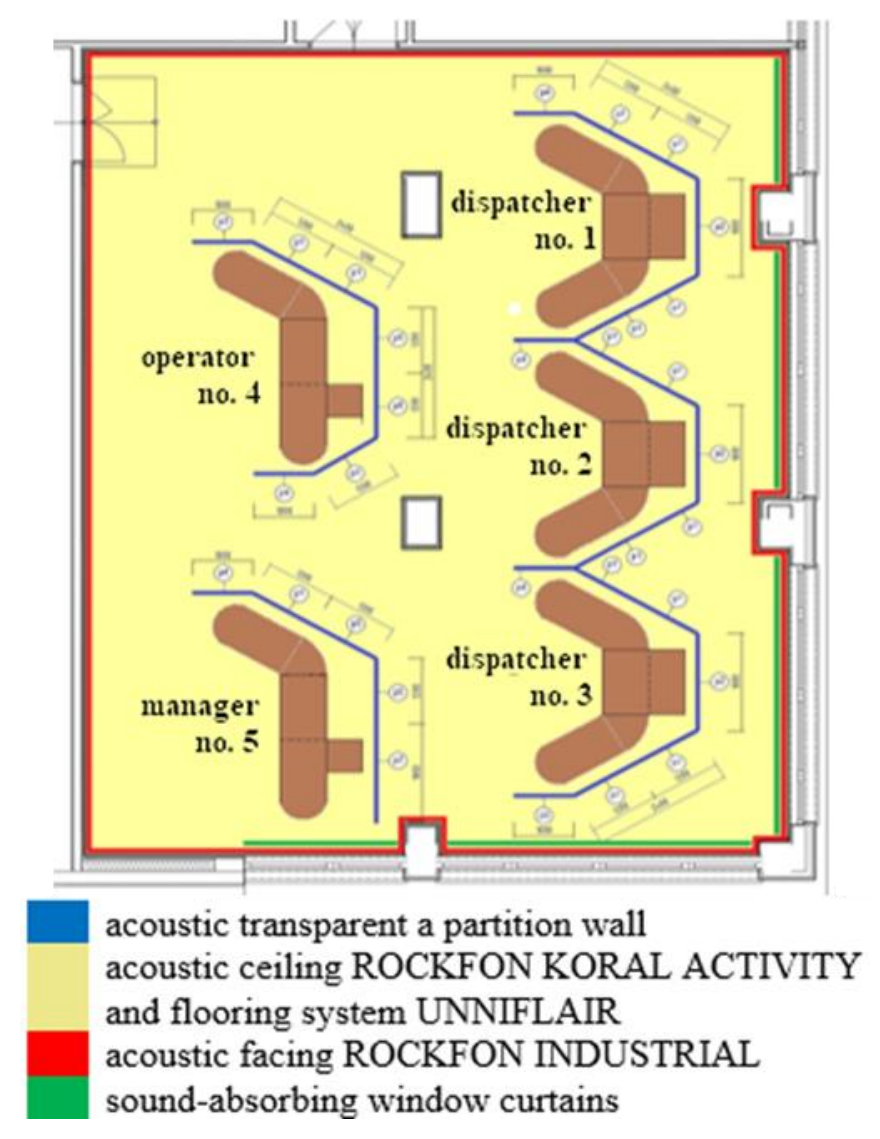

Fig. 3 Modifications to the TMC working environment in terms of internal noise attenuation [9]

After applying these adjustments, re-measurements and simulation were made to verify their efficacy. For the reason of objectivization, the measurement was carried out by the same method, at the same daytime and interval as the previous measurements [9].

\section{RESULTS AND DISCUSSION ON RESULTS}

Today, many companies use open-space offices designed to increase teamwork, communication and productivity. However, studies show that those open interactive spaces are a source of workplace noise and that the noise as an unwanted sound is a common problem in such offices [2].

Former basic precautions aimed at using soundproofing of ceilings, walls, floors and applying absorbent hinges to windows have reduced the noise by $1.7 \mathrm{~dB}$. The reason for this is the prevalence of noise from individual TMC sites and direct propagation, not reflections from the reflective areas of the room. Reducing surface reflectivity alone has no potential to substantially reduce the TMC noise.

Another proposal was the application of acoustic transparent partition wall in two variants. In Figure 4, a noise spreading simulation in the form of an acoustic map is shown, using an acoustic transparent partition wall $150 \mathrm{~cm}$ high, and a wall up to the ceiling of the room. 


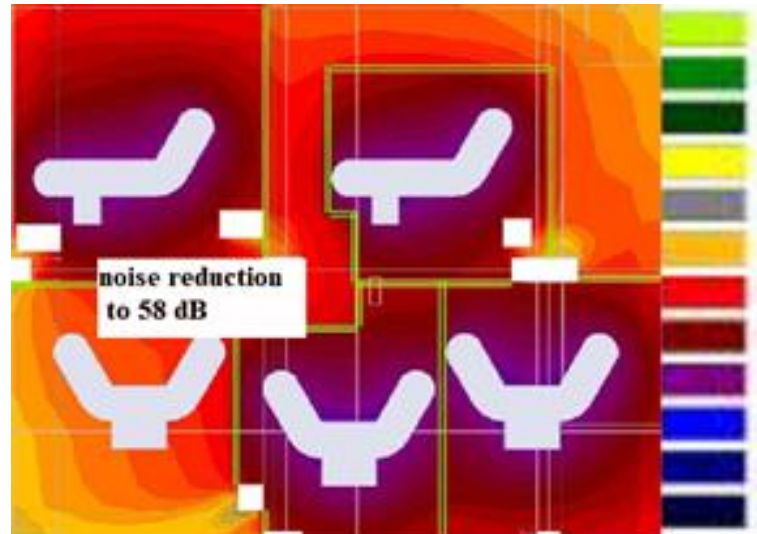

a)

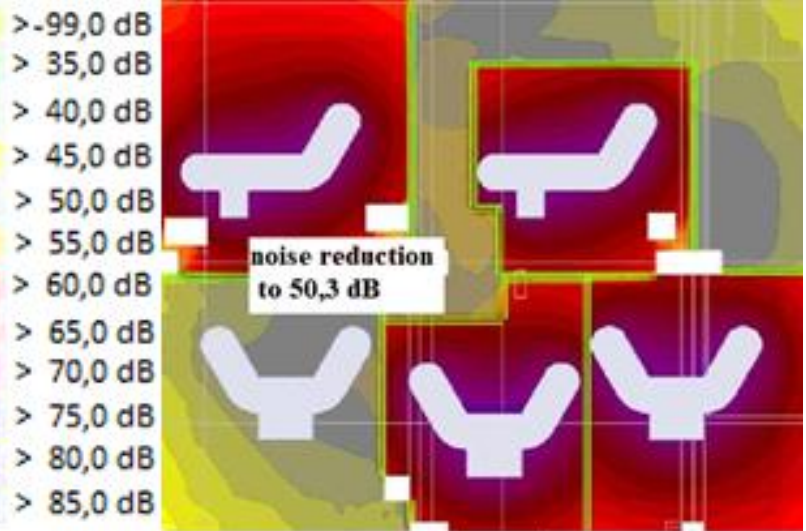

b)

Fig. 4 Acoustic map after application of the acoustic transparent partition wall:

a) acoustic transparent partition wall $150 \mathrm{~cm}$ high,

b) acoustic transparent partition wall up to ceiling of room [9]

From the simulation results, it is clear that the greatest reduction in noise is achieved by applying the acoustic transparent partition wall up to the ceiling of the room. Owing to the requirements of employees, the Commission selected the variant a) $150 \mathrm{~cm}$ high acoustic transparent partition wall. After computer simulations, real noise measurements were also made at the workplace after application of the acoustic transparent partition wall $150 \mathrm{~cm}$ high. Figure 5 shows the location of the measurement points in the TMC workstation.

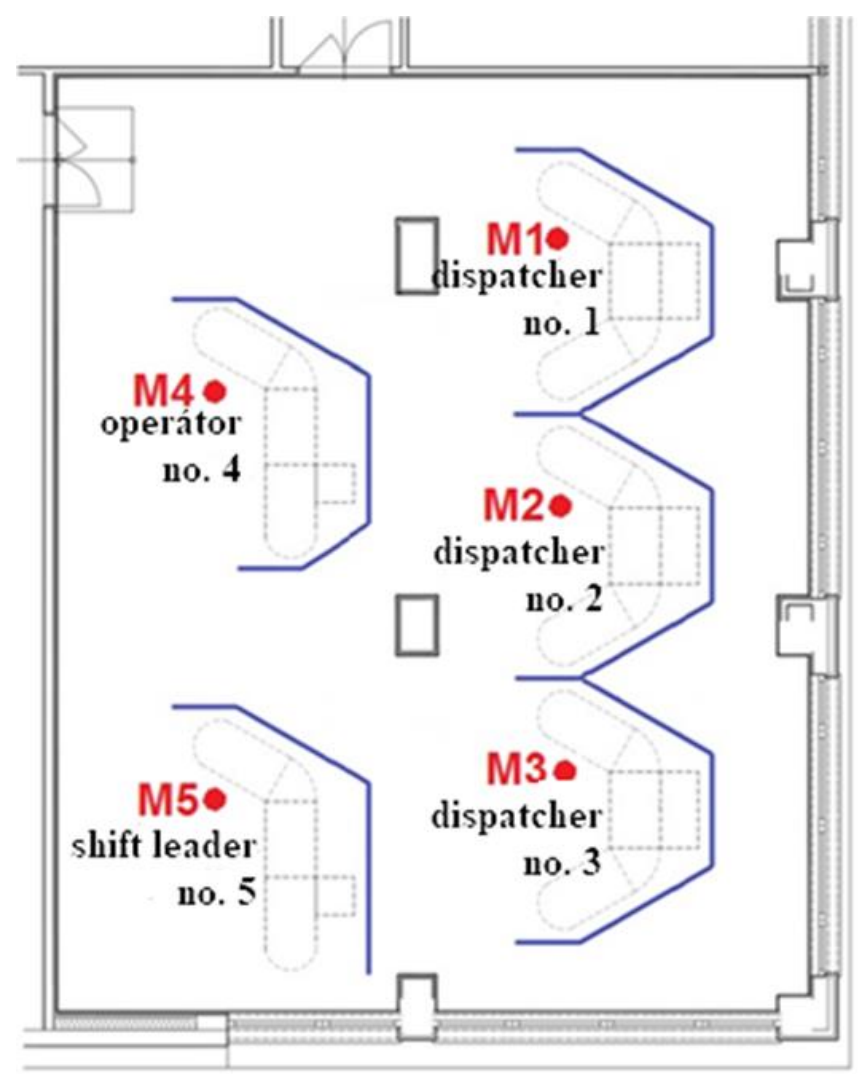

Fig. 5 Measuring points for re-measurement and verification of the effectiveness of the proposed measures [9] 
In the following Table, the values obtained by the measurement at the indicated measuring points according to Figure 5.

In terms of organizational measure, in individual jobs, after 6 hours of workshift and lunch break of 30 minutes, rotation of RCT dispatchers is conducted..

Table 5 Measured noise levels of individual professions after the implementation of anti-noise measures

\begin{tabular}{|c|c|c|c|c|c|c|}
\hline $\begin{array}{c}\text { Working place/ } \\
\text { measurement } \\
\text { point }\end{array}$ & \multicolumn{2}{|c|}{$\begin{array}{c}\text { Time interval of } \\
\text { measurement I. } \\
\text { from-to }\end{array}$} & $\begin{array}{c}\text { Measured } \\
\text { value } \\
\boldsymbol{L}_{\text {Aeq, } \boldsymbol{T}} \\
{[\boldsymbol{d B}]}\end{array}$ & \multicolumn{2}{|c|}{$\begin{array}{c}\text { Time interval } \\
\text { of measurement } \\
\text { II. } \\
\text { from-to }\end{array}$} & $\begin{array}{c}\text { Measured } \\
\text { value } \\
\boldsymbol{L}_{\text {Aeq, } \boldsymbol{T}} \\
{[\mathbf{d B}]}\end{array}$ \\
\hline M1 - dispatcher 1 & $11: 29$ & $11: 32$ & 48.94 & $15: 15$ & $15: 18$ & 61.76 \\
\hline M2 - dispatcher 2 & $11: 34$ & $11: 37$ & 49.08 & $15: 19$ & $15: 22$ & 53.85 \\
\hline M3 - dispatcher 3 & $11: 38$ & $11: 41$ & 57.56 & $15: 23$ & $15: 26$ & 55.51 \\
\hline M4 - operator & $11: 43$ & $11: 46$ & 44.66 & $15: 27$ & $15: 30$ & 52.61 \\
\hline M5 - shift leader & $11: 47$ & $11: 50$ & 43.99 & $15: 31$ & $15: 34$ & 56.80 \\
\hline
\end{tabular}

Determination of noise exposure on the health of employees in the TMC, it is important to take into account the effects during a work shift.. Table 6 shows the values also with respect to the interval of action.

\begin{tabular}{|c|c|c|c|c|c|}
\hline \multicolumn{6}{|c|}{ Table 6 Result of daily A level of exposure to noise $L_{E X, 8 h}$} \\
\hline $\begin{array}{c}\text { Work } \\
\text { activity } \\
\text { /measureme } \\
\text { nt point }\end{array}$ & $\begin{array}{c}\text { Measured } \\
\text { value } \\
L_{A e q, T} \\
{[d B]}\end{array}$ & $\begin{array}{c}\text { Interval } \\
\text { of action } \\
{[\boldsymbol{h}]}\end{array}$ & $\begin{array}{c}\text { Measured } \\
\text { value } \\
L_{A e q, T} \\
{[d B]}\end{array}$ & $\begin{array}{c}\text { Interval } \\
\text { of action } \\
{[h]}\end{array}$ & $\begin{array}{c}\text { Measured } \\
\text { value } \\
\text { recalculated } \\
\text { on the } L_{E X, 8 h} \\
{[d B]}\end{array}$ \\
\hline dispatcher 1 & 48.94 & 6 & 56.80 & 5.5 & 54.16 \\
\hline dispatcher 2 & $49 . .08$ & 6 & - & - & 49.08 \\
\hline dispatcher 2 & - & - & 53.85 & 5.5 & 53.85 \\
\hline dispatcher 3 & 57.56 & 6 & 55.51 & 5.5 & 59.67 \\
\hline operator & 44.66 & 6 & 52.61 & 5.5 & 53.26 \\
\hline shift leader & 43.99 & 6 & 61.76 & 5.5 & 61.83 \\
\hline
\end{tabular}

From the results it is clear, that the noise exposure limit value is exceeded for all measured professions, but only in two workplaces the value exceeded $58 \mathrm{~dB}$. The value of $58 \mathrm{~dB}$ represents the value obtained by the simulation after the installation of an acoustic transparent partition wall $150 \mathrm{~cm}$ high, which was selected for the implementation of the measures in terms of attenuation of internal noise. Whereas, there is an implemented rotation of employees in two jobs in one work shift, one measurement shows a low value, because the employee will spend another part of the shift in a different workplace outside the TMC.

\section{CONCLUSION}

Since the measured values showed an excessive value of the standardized noise level $L_{A E X, 8 h}$ for work group II - the dispatcher, further action is needed. The proposed solutions to 
reduce the spread of noise in the TMC was chosen by the Commission. The separation screens $150 \mathrm{~cm}$ high from the floor, enabling visual contact were used. The resulting outlook simulation showed only a small reduction in noise to $58 \mathrm{~dB}$ compared to the model for a comprehensive acoustic separation of workplaces from floor to ceiling with visual contact retention, which, with the resulting outlook simulation, showed a stop in the spread of noise between the workplaces in a straight line and allowed the noise to be reduced to $50.3 \mathrm{~dB}$. The choice was due to the specific requirements of the users who, on the one hand, requested the decreased exposure of noise from other sites but, on the other hand, demanded to preserve visual contact as well as the ability to communicate with each other during workshift for operational work tasks.

The noise level inindividual TMC workplaces was partially reduced to the value of the modeled noise situation. Replacing floorboards by textile flooring with sound absorbing properties and making acoustic ceilings, wall and pillar lining with the addition of the thick textile sound-absorbing window hinges greatly reduced the spread of noise. This further allows to decrease communication device setup volume, thus also possibility to apply initial condition of noise reduction and eliminating noise at the source itself [9].

\section{Acknowledgement}

This research output was supported by the Slovak Research and Development Agency under the contract No. APVV-16-0223.

This research output was also supported by the KEGA under the contract No. 030UMB4/2017.

\section{References}

[1] Non-binding guide to good practice for the application of Directive 2003/10/EC of the European Parliament and of the Council on the minimum safety and health requirements regarding the exposure of workers to the risks arising from physical agents (Noise). Luxembourg: Office for Official Publications of the European Communities, 2008. 169 s. ISBN 978-92-79-08411-9.

[2] MAXWELL, L. E. Noise in the Office Workplace. Ithaca New York, USA. : Media and Technology Services at Cornell University, College of Human Ecology. [Online]. [Accessed: 04 -2019] Available at https://dea.human.cornell.edu/sites/default/files/pdf/fpm-notes_vol1_number11.pdf.

[3] Noise may endanger employees' health. Workplace. Farmingdale, New York : USA Today Magazine, 2002. ISSN 0161-7389.

[4] McEwen, B. S. 1998. Protective and damaging effects of stress mediators. New England Journal of Medicine, 38(3), $171-177$.

[5] KJELBERG, A., AND SKOLDSTROPM, B. 1991. Noise annoyance during the performance of different nonauditory task. Perceptual and Motor Skills, 73: 39- 49.

[6] SINAY, J., BALÁŽIKOVÁ, M. 2012. Implementation of Auditory and Non-Auditory Effects of Noise in the Risk Assessment Process in Mechanical Engineering. Procedia Engineering, Volume 48, 2012, p. 621-628, [Online]. [Accessed: 04 - 2019] Available at http://www.sciencedirect.com/science/article/pii/S1877705812046255. ISSN 1877-7058.

[7] REICHL, J., VŠETIČKA, M. 2006-2014.Účinek hluku na lidský organismus (Noise effects on human organism). Encyklopedie fyziky. [Online]. [Accessed: 04 - 2019]. Available at http://fyzika.jreichl.com/main.article/view/202-ucinek-hluku-na-lidsky-organismus.

[8] FRIMEL, M. Manažment hluku a životný cyklus výrobných stavieb (Noise management and lifecycle of production structures). Košice: FvT TUKE. ISSN 1335-0285. ISSN 1335-0285.

[9] Railways of the Slovak Republic. internal document. [Accessed: 2019].

[10] Law no. 115/2006 Z.z. o minimálnych zdravotných a bezpečnostných požiadavkách na ochranu zamestnancov pred rizikami súvisiacimi s expozíciou hluku (Act No. 115/2006 Coll. on the minimum health and safety requirements for employees protection from the noise-related risks). 
[11] LIBERKO, M. 2004. Hlukv prostředí: problematika a řešeni (Noise in environment: problem and solution). PrahaEuropean Environment Agency: Ministerstvo životního prostředí, 27 s. ISBN 80721-2271-1.

\section{ORCID}

Pavol Čekan

0000-0002-7435-726X 